\title{
Thyroxine-Binding Globulin
}

National Cancer Institute

\section{Source}

National Cancer Institute. Thyroxine-Binding Globulin. NCI Thesaurus. Code C106005.

Thyroxine-binding globulin (415 aa, $\sim 46 \mathrm{kDa}$ ) is encoded by the human SERPINA7 gene.

This protein plays a role in both binding to and transport of both thyroxine and triiodothyroxine. 